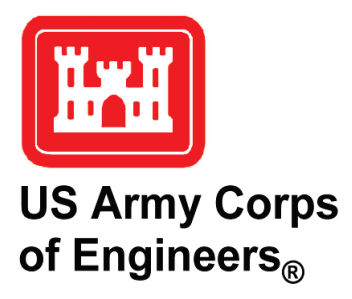

\title{
Coastal Foredune Evolution, Part 1: Environmental Factors and Forcing Processes Affecting Morphological Evolution
}

by Katherine L. Brodie ${ }^{1}$, Margaret L. Palmsten ${ }^{2}$, Nicholas J. Spore ${ }^{1}$

PURPOSE: This Coastal and Hydraulics Engineering Technical Note (CHETN) is the first of two CHETNs focused on improving technologies to forecast coastal foredune evolution. Part 1 summarizes the short-, meso-, and multi-decadal-timescale environmental factors and forcing processes that influence the morphodynamic evolution of coastal foredunes. Part 2 reviews modeling approaches to forecast these changes and develops a probabilistic modeling framework to calculate foredune evolution that includes both erosion and growth processes.

INTRODUCTION: Coastal foredunes along developed coastlines are dynamic features that continually evolve in response to changing coastal dynamics, aeolian processes, and management decisions (e.g., Swann et al. 2015). Predicting their morphologic evolution is important to coastal engineers and managers because they provide ecosystem services and can reduce storm damages to coastal infrastructure, both of which increase the resiliency of coastal areas. A recent report documenting dune management challenges on developed coasts (Elko et al. 2016) specifically identified the need to expand both observations and modeling approaches across meso-timescales that were more directly related to the operational scale of coastal dune and beach management decisions and programs (e.g., over months to decades). However, the challenge lies in incorporating enough short-term processes to predict medium- and long-term evolution accurately in a computationally efficient manner, as well as validating month-to-decadal evolution predictions with observations.

Part 1 of this two-part series summarizes the significant processes, controlling factors, and morphologic response on short-, meso-, and multi-decadal-timescales; highlights significant mesoscale observations; and concludes with a summary of significant findings.

SHORT-TIMESCALES: Foredune evolution on short-timescales (seconds to days) has been the focus of a number of field studies documenting wind- and wave-driven morphological evolution. During dry, high-wind events, sand is transported from the sub-aerial beach and deposited in the dune, leading to dune growth or landward migration depending on the geometry of the system. In contrast, during severe storms with elevated waves and water levels, sand is removed from the dune and deposited on the beach face or moved to the surf-zone, leading to dune erosion. The magnitude and duration of the primary driving force - wind speeds and fetch distance for aeolian processes (e.g., Bauer and Davidson-Arnott 2003) and wave and water level heights for the hydrodynamic processes (e.g., Sallenger 2000) — relative to the sediment characteristics of the beach-dune system exert first-order control on the morphological response of the dune to both

\footnotetext{
${ }^{1}$ U.S. Army Engineer Research and Development Center, Coastal and Hydraulics Laboratory, Duck, NC

${ }^{2}$ Naval Research Laboratory, Stennis Space Center, MS
} 
processes. The complexities of the environmental forcing parameters controlling these processes on short-timescales are discussed next.

Wave-Driven Erosion. Dunes erode when hydrodynamic forcing (total water levels) exceeds the elevation of morphological features on the dune, such as its toe or crest (e.g., Sallenger 2000), bringing waves into contact with different portions of the dune. Total water levels are a combined effect of astronomical tide, regional storm surge, and wave-driven setup and runup. Wave-driven erosion of dunes can be simplified into three impact regimes: collision, overwash, and inundation. Each of these impact regimes has characteristic morphodynamic responses (Sallenger 2000).

When total storm water levels are above the dune toe but lower than the dune crest, wave bores and swash collide with the dune, and the dune responds by slumping or scarping. Palmsten and Holman (2011) demonstrated that contact between waves and the base of the dune leads to infiltration, which in combination with impact forces from incoming wave bores (Larson et al. 2004) create failure planes and slope instabilities within the dune face. As the infiltrated wet dune sediment becomes heavier, the destabilizing forces on the failure plane exceed the resisting force of the sediment, and the wetted dune sediments slump off the dune face leaving a vertical scarp (Palmsten and Holman 2012; Nishi and Kraus 1996). Depending on the magnitude of sequential wave runups, this slump block is then eroded away or remains at the toe of the dune, effectively increasing the elevation of the dune toe. Thus the magnitude of dune erosion during a storm event scales with the length of exposure of the dune face to incoming waves and the rate of infiltration into the dune, which is a function of the sediment characteristics that affect its hydraulic properties such as grain size distribution, bulk density, and organic content (Palmsten and Holman 2012). Accurately predicting the frequency of wave contact with the base of the dune (an elevation which may evolve throughout the course of the storm) appears to be as important as the processes causing dune face failure. Laboratory (Palmsten and Holman 2012) and field investigations (Splinter and Palmsten 2012), however, provide conflicting conclusions on whether the $2 \%$ exceedance elevation of runup or a lower elevation (e.g., 16\% exceedance elevation) should be used when determining exposure timescales of the dune face.

Storm impacts that result in dune overwash and inundation are significantly more catastrophic to the dune system. Overwash occurs when total storm water levels exceed the dune crest whereas inundation occurs when mean storm water levels (tides + surge) exceed the dune crest. Overwash lowers dune crests and widens the gaps between dunes (Houser et al. 2008; Houser 2013). In contrast, inundation initiates widespread dune system failure and removes sediment from the active sub-aerial coastline (Sallenger et al. 2007). Alongshore variability in the height of dune systems can be significant (Thieler and Young 1991; Houser et al. 2008; Houser and Matthew 2011) and can lead to increases in rates of dune erosion during storms if there is lateral erosion of overwash channels (Pries et al. 2008; Houser 2013). Specifically, Houser (2013) noted that the majority of dune crest elevation change during overwash is the result of lateral slumping of adjacent dune sidewalls that border the overwash channel, not overtopping of the dune itself. Inclusion of alongshore variations and gradients in dune crest elevations may therefore be important for accurately predicting dune morphological evolution in overwash regimes-processes that are not accounted for in one-dimensional (1D) cross-shore morphodynamic models.

Wind-Driven Recovery. Dunes recover when aeolian forces mobilize sediment on the subaerial beach and transport it landward, depositing it when wind speeds reduce due to flow 
feedbacks around topographic features and vegetation on the back beach (Hesp 1988; Hesp 2002; Davidson-Arnott 2010). Wind stress, grain size, and sand supply exert the greatest control on sediment flux to the dune. However, other factors including the moisture content of the beach (from either precipitation, inundation by waves, or water-table effects [Davidson-Arnott et al. 2005]), vegetation type and cover (e.g., Buckley 1987; Hesp 1989), topographic slope breaks (Walker et al. 2009), grain size sorting, and bed roughness introduce complexities that affect the efficiency of these transport processes (Sherman and Hotta 1990).

The available sand supply for the dune is a function of the available fetch distance, which in turn is a function of the instantaneous sub-aerial beach width and the direction of prevailing winds (Nordstrom and Jackson 1993; Bauer and Davidson-Arnott 2003; Hesp et al. 2005; DelgadoFernandez 2010). Bauer and Davidson-Arnott (2003) note there is an important distinction between the available fetch (the wind-parallel distance across the sub-aerial beach) and the critical fetch distance - the needed sand fetch to achieve maximum sediment transport for a given wind speed and grain size. Critical fetch accounts for the distance it takes the saltation system to initiate and adjust to an equilibrium state. Critical fetch depends on both the relative beach-wind geometry as well as sediment characteristics, such as grain size and moisture content; however, a ubiquitous equation to predict critical fetch given these parameters does not presently exist and is an active area of research. Bauer et al. (2009) observed short-term variations (minutes to hours) in sediment transport rates on a narrow beach during the initiation of a storm event that were directly related to changes in wind speed and direction (and resultant critical fetch) over the same timescales. High-speed, shore-oblique winds generated the highest sediment flux to the dune. However, sediment moisture content varied in time with increasing precipitation associated with the passing of the storm and in space-time through alongshore and temporal variations in wave runup associated with the tide, growing wave heights, and spatially variable morphology (Bauer et al. 2009). The variations in moisture content mediated the effects of high winds. The observations of Bauer et al. (2009) demonstrate the important link between hydrodynamic and aeolian processes. Models that link these processes are necessary to estimate the available sand supply and predict sediment flux to the dune accurately.

As onshore or shore-oblique winds blow across the beach face, morphological features of the beach, such as the presence of beach cusps or tall berms, impact the air-flow field (Short and Hesp 1982; Hesp 1999; Walker et al. 2006; Hesp et al. 2013). If beach morphology has low roughness, there is minimal flow disturbance, and sediment transport can reach a maximum whereas beaches with three-dimensional features such as cusps or berms lead to flow disturbances (accelerations and decelerations over morphology), which reduce aeolian sediment transport (Sherman and Lyons 1994; Sherman and Bauer 1993; Short and Hesp 1982). Some field studies have observed the development of wind jets, localized high-speed flows on the timescales of seconds to minutes, which can rapidly transport significant amounts of sand over abrupt changes in topography such as the crest of the dune or beach scarps (Arens 1996; Hesp et al. 2013; Hesp and Smyth 2016). Walker et al. (2009) observed the shoreward dune face steering near-surface flows, leading to variations in vertical wind profiles and sediment transport patterns over concave and convex dune shapes due to differences in slope and curvature. Airflow patterns over steep, shoreward scarped faces of dunes have been observed to lead to rapid rebuilding at the dune base (on the timescale of hours) during high winds (Aagaard et al. 2004; Christiansen and Davidson-Arnott 2004). The type and density of vegetation on the dune also affects sediment transport processes by altering airflow over the sand surface, similar to topographic slope breaks and other surface roughness features 
(Hesp et al. 2013). The vegetation absorbs momentum from the wind, reducing bed shear stresses and lowering sediment transport rates (Zarnetske et al. 2015). Under some conditions, feedbacks between the vegetation and the airflow can cause the vegetation to offer additional protection for the bed as vegetation is deflected by the wind (Hesp et al. 2013). Beach roughness elements, whether topographically or vegetation based, and the associated flow feedbacks are critical components of dune morphological evolution (e.g., Duran and Moore 2013).

MESO-TIMESCALES: The morphodynamic evolution of coastal foredunes over years to decades is often the most pertinent timescale for making coastal management decisions (Elko et al. 2016). However, this timescale has received less attention compared with the short-term evolution or with the long-term evolution of the barrier island. Meso-scale coastal morphological evolution is a result of feedbacks and non-linear interactions between many physical processes, making this timescale complicated to study (see Ruggiero et al. [2016] for a discussion of processes affecting prograding beach-dune morphodynamics at decadal timescales). For example, a beach that experiences enough wind stress to initiate aeolian sand transport will not undergo dune growth if sand remains in surf-zone sandbars and the beach has short fetches resulting in a limited sediment supply (e.g., Houser 2009). This first sub-section will address surf-zone/beach/dune interactions at the meso-timescale and their effect on dune morphological evolution. The second subsection will then focus on the importance of sequences of storms.

Surf-Zone/Beach/Dune Interactions. The intertidal zone of beaches, where sandbars weld to the shoreline, is a large source of sediment for the sub-aerial beach (Aagard et al. 2004; Houser 2009; de Vries et al. 2014; Ruggiero et al. 2016). On intermediate and dissipative beaches, surfzone sandbars can migrate landward and weld to the shoreline, merging with the beach (Houser and Greenwood 2003; Masselink et al. 2006; Ruggiero et al. 2009; Cohn et al. 2015). The process of bar welding creates large fetches, thereby increasing the potential for sediment flux to the dune (Davidson-Arnott 1988; Aagard et al. 2004; Anthony et al. 2006). Hesp (1988, 2012) notes that as the back beach grows in elevation, inundation by waves becomes less frequent, which results in decreasing moisture content and increasing likelihood for aeolian transport and dune growth. Intermediate and reflective beaches may have steep foreshores and variable topography that create variations in the wind field across the profile and may limit aeolian transport despite a seemingly wide beach (Sherman and Lyons 1994; Hesp 1999). Thus, surf-zone/beach state (Wright and Short 1984) climatology can be linked to dune morphological evolution on the meso-scale such that beaches that tend to be wide, flat, and dissipative have the maximum potential for aeolian transport, and steep, narrow, reflective beaches have the least potential for aeolian transport. Intermediate beaches oscillate between these two end-points in both space and time depending upon the morphodynamics of the system (Hesp 2012; Houser and Hamilton 2009). While the surfzone and dune may interact explicitly during extreme events, during the majority of conditions the sub-aerial beach acts as the link between these two systems. Subaerial morphology (elevation, width, topographic variability), as discussed above, can therefore exert control on the processes responsible for dune growth and evolution. Predicting the morphology of the beach at the shoreline is still an active research topic, particularly at these meso-timescales, and may be a critical component of predicting coastal foredune evolution.

Importance of Storm Sequencing. Lee et al. (1998) first recognized the importance of sequential storms on the morphology of the beach/nearshore system, noting that several storms in quick succession can lead to rapid erosion of the nearshore profile since the profile cannot recover 
between storms. Lee et al. (1998) noted that a series of moderate storms can have an equal or greater cumulative effect than a single large storm. Splinter et al. (2014) suggested that erosion during a given storm event is a function of the storm itself and the antecedent condition of the beach (recent storm history). Splinter et al. (2014) found that cumulative wave power and cumulative energy density explained more than $94 \%$ of the variability in modeled dry beach erosion during the passage of seven storms in a 6-month period on the Gold Coast of Australia.

In a study of the recovery of Santa Rosa Island, FL, to Hurricanes Opal, Ivan, and Katrina, Houser and Hamilton (2009) noted that alongshore variations in both storm impacts and recovery events were correlated to locations of historical storm impacts and resultant pre-storm morphology. They found that if the beach-dune system does not have adequate time to recover before the next large storm event, alongshore variations in topography and island recovery were reinforced by the subsequent storms (Houser and Hamilton 2009). This suggests that periods of frequent storms may lead to alongshore variable morphology, which increases island susceptibility to future events (Houser 2013) and decreases coastal resilience. Houser et al. (2015) developed a conceptual model for post-storm beach and dune recovery. They noted that the discrepancy in timescales between erosion (hours to days) and recovery (years to decades) of dunes creates a system that is highly sensitive to sequences of storms and noted the effect of the sensitivity on the coupled morphodynamic response of the sub-aerial beach and surf-zone system. Storm frequency may also modulate ecomorphodynamic feedbacks because periods of frequent or large magnitude storms promote burial tolerant species that recolonize overwash deposits and lead to lower dunes (Duran and Moore 2013; Wolner et al. 2013). In contrast, if there is sufficient time between storms, dune grasses will begin to colonize the area and trap wind-blown sand promoting high-elevation dunes that are less likely to be inundated frequently during storms (Duran and Moore 2013). Bio-physical feedbacks between species growth rates, trapping efficiency, and the wind-flow can be integrated over multi-annual timescales to explain variations in dune morphological characteristics under similar physical forcing (Zarnetske et al. 2015).

MULTI-DECADAL-TIMESCALES: Few studies documenting beach and dune morphological evolution at multi-year to multi-decadal timescales exist, largely due to funding constraints on collecting morphological monitoring data sets at these long timescales. The authors have identified four studies along the U.S. west and Gulf coasts, and Australian southeast coasts that are notable exceptions.

Ruggiero et al. (2016) documented the morphodynamic evolution of high-energy, prograding, dissipative beaches in the Columbia River littoral cell in the U.S. Pacific Northwest over seasonalto-century timescales using observations and models. They observed two types of dune growththe progradation and development of new dune ridges (e.g., Long Beach, WA) and the vertical aggradation of a single dune ridge (e.g., Clatsop Plains, OR). The prograding dune grew seaward at a rate of 5.31 meters/year $(\mathrm{m} / \mathrm{yr})$ and upward at a rate of $0.36 \mathrm{~m} / \mathrm{yr}$ whereas the aggrading dune grew seaward at a rate of $3.47 \mathrm{~m} / \mathrm{yr}$ and upward at a rate of $0.49 \mathrm{~m} / \mathrm{yr}$. Ruggiero et al. (2016) showed that onshore intertidal sandbar migration during calm conditions at both sites led to progradation and aggradation of the subaerial beach of roughly $10 \mathrm{~m}^{3} / \mathrm{m} / \mathrm{yr}$ at decadal timescales. These bar-welding events then generated large fetches and sediment fluxes to the foredune. Ecomorphodynamic feedbacks between vegetation species and sediment supply explained the development of either multiple prograding dune ridges or high aggrading single dune ridges. 
Houser et al. (2015) used a series of airborne lidar topographic data sets from 2004 to 2010 to study the evolution of Santa Rosa Island, FL, during the passage of Hurricanes Ivan, Dennis, and Katrina. Santa Rosa Island is a dissipative, low-energy beach with alongshore variable nearshore bathymetry (a series of transverse ridges; Houser et al. 2008). Houser et al. (2015) investigated spatial and temporal variations in the rate of foredune growth and recovery following overwash during the passage of the hurricanes. They observed that recovery rates followed a sigmoid curve but with large alongshore variations in growth rate $(\sim 0.1$ to $\sim 0.55 \mathrm{~m} / \mathrm{yr})$, which was inversely correlated to pre-storm dune height. The dunes on Santa Rosa Island did not begin to recover until the profile reached its pre-storm elevation. Houser et al. (2015) also compared these recovery rates and patterns to data from Galveston Island, TX, from Morton et al. (1994) (presented below) and observed slower growth rates for Santa Rosa Island.

Morton et al. (1994) observed the evolution of a series of cross-shore profiles along Galveston Island, TX, from 1983 to 1993. Galveston Island is a micro-tidal, low-wave energy, intermediate beach that was subjected to a series of hurricanes in the 1980s. The hurricanes caused significant dune erosion in some locations and complete removal of the foredune in other locations. Morton et al. (1994) noted that dune regrowth was greatly hampered on developed portions of the island where coastal structures confined beach widths and did not provide accommodation space for aeolian transport and dune re-growth. Morton et al. (1994) observed that beach and dune recovery required 4 to 5 years for dunes to reach their pre-storm elevation and that only a few locations along the island completely recovered. Morphodynamic feedbacks with the surf-zone and various alongshore hydrodynamic and engineered features (tidal inlets, jetties, crescentic nearshore bars) created highly alongshore variable recovery rates.

McLean and Shen (2006) utilized 30 years of beach profile data at a micro-tidal, moderate-to-high energy intermediate beach in South East Australia (Moruya Beach) to investigate conditions leading to foredune redevelopment following dune destruction. Foredune development did not begin until a backshore berm of 2.3-2.8 m above mean sea level with a cross-shore width of greater than $30 \mathrm{~m}$ developed. Once this elevated backshore berm was developed, McLean and Shen (2006) observed dune aggradation and progradation of approximately $2 \mathrm{~m}$ in 15 years.

SUMMARY OF FINDINGS: Models of dune morphological evolution on meso-timescales must incorporate short- and medium-term forcing and environmental factors, such as vegetation and variation in regional morphology. A numerical modeling framework (discussed in Part 2) is based on the significant findings summarized below.

- The frequency, duration, and elevation of wave contact with the dune exerts a primary control on dune erosion processes at both short- (e.g., during a storm) and meso-timescales (e.g., sequences of storms).

- Alongshore variations in dune morphology can enhance erosion at both short- (e.g., allowing for lateral erosion during overwash) and meso-timescales (e.g., increased susceptibility to damage in persistent locations during stormy periods).

- Wind speed and fetch distance exert the primary controls on whether sub-aerial beach sediment is mobilized and transported to the dune. The timing of precipitation and high frequency variations in wind speed and direction relative to the beach orientation at the beginning of coastal storms can have large effects on whether aeolian sediment transport occurs during coastal storms. 
- Hydrodynamic, aeolian, and ecological processes must be integrated to accurately predict the available sand supply, resultant sediment flux to the dune, and the dune geomorphology. To that end, the relative timing of wind speeds, precipitation, and water levels is what drives dune evolution at short-timescales whereas at meso-timescales the specific sequencing of these storms may be most important for determining dune evolution.

- Wide, flat, and dissipative beaches have the maximum potential for aeolian transport. Steep, narrow, and reflective beaches have the least potential for aeolian transport. Subaerial morphology (elevation, width, topographic variability) can therefore exert control on the processes responsible for dune growth and evolution.

- The four studies documenting meso-timescale observations demonstrated how nearshore evolution through sandbar welding can promote foredune progradation and vertical accretion, how vegetation can affect dune evolution, and the importance of pre-storm morphology recovery of beach width and engineered features.

ADDITIONAL INFORMATION: For additional information, contact Katherine L. Brodie, Coastal Observation and Analysis Branch, Coastal Hydraulics Laboratory, 1261 Duck Road, Duck, NC 27949, at 252-261-6840 x233 or email: Katherine.L.Brodie@usace.army.mil. This research was funded by the U.S. Army Corps of Engineers, Coastal Inlets Research Program (CIRP), in response to Statements of Need to improve the resiliency of beaches. Additional information pertaining to CIRP may be obtained from the Program Manager, Dr. Julie Rosati, at Julie.D.Rosati@usace.army.mil. This CHETN should be cited as follows:

Brodie, K. L., M. L. Palmsten, and N. J. Spore. 2017. Coastal foredune evolution, Part 1: Environmental factors and forcing processes affecting morphological evolution. ERDC/CHL CHETN-II-56. Vicksburg, MS: U.S. Army Engineer Research and Development Center. http://dx.doi.org/10.21079/11681/21468

\section{REFERENCES}

Aagaard, T., R. Davidson-Arnott, B. Greenwood, and J. Nielsen. 2004. Sediment supply from shoreface to dunes: Linking sediment transport measurements and long-term morphological evolution. Geomorphology 60(1):205224.

Anthony, E. J., S. Vanhee, and M. H. Ruz. 2006. Short-term beach-dune sand budgets on the north sea coast of France: Sand supply from shoreface to dunes, and the role of wind and fetch. Geomorphology 81(3-4):316-329.

Arens, S. M. 1996. Patterns of sand transport on vegetated foredunes. Geomorphology 17(4):339-350.

Bauer, B. O., and R. G. Davidson-Arnott. 2003. A general framework for modeling sediment supply to coastal dunes including wind angle, beach geometry, and fetch effects. Geomorphology 49(1-2):89-108.

Bauer, B. O., R. G. D. Davidson-Arnott, P. A. Hesp, S. L. Namikas, J. Ollerhead, and I. J. Walker. 2009. Aeolian sediment transport on a beach: Surface moisture, wind fetch, and mean transport. Geomorphology 105(1-2):106116.

Buckley, R. 1987. The effect of sparse vegetation on the transport of dune sand by wind. Nature 325(6103):426-428.

Christiansen, M. B., and R. Davidson-Arnott. 2004. Rates of landward sand transport over the foredune at Skallingen, Denmark, and the role of dune ramps. Geografisk Tidsskrift-Danish Journal of Geography 104(1):31-43. 
Cohn, N., D. Anderson, and P. Ruggiero. 2015. Observations of intertidal bar welding along a high energy, dissipative coastline. In The Proceedings of the Coastal Sediments 2015.

Davidson-Arnott, R. G. 1988. Temporal and spatial controls on beach/dune interaction, Long Point, Lake Erie. Journal of Coastal Research Special Issue No. 3:131-136.

Davidson-Arnott, R. G., K. MacQuarrie, and T. Aagaard. 2005. The effect of wind gusts, moisture content and fetch length on sand transport on a beach.Geomorphology 68(1-2):115-129.

Davidson-Arnott, R. 2010. Introduction to coastal processes and geomorphology. Cambridge, UK: Cambridge University Press.

Delgado-Fernandez, I. 2010. A review of the application of the fetch effect to modelling sand supply to coastal foredunes. Aeolian Research 2(2-3):61-70.

de Vries, S., J. S. M. van Thiel de Vries, L. C. van Rijn, S. M. Arens, and R. Ranasinghe. 2014. Aeolian sediment transport in supply limited situations. Aeolian Research 12:75-85.

Durán, O., and L. J. Moore. 2013. Vegetation controls on the maximum size of coastal dunes. Proceedings of the National Academy of Sciences 110(43):17217-17222.

Elko, N., K. Brodie, H. Stockdon, K. Nordstrom, C. Houser, K. McKenna, L. Moore, J. Rosati, P. Ruggiero, R. Thuman, and I. Walker. 2016. Dune management challenges on developed coasts. Shore \& Beach 84(1):15.

Hesp, P. 1988. Surfzone, beach, and foredune interactions on the Australian South East Coast. Journal of Coastal Research Special Issue No. 3:15-25.

Hesp, P. A. 1989. A review of biological and geomorphological processes involved in the initiation and development of incipient foredunes. Proceedings of the Royal Society of Edinburgh. Section B. Biological Sciences 96:181201.

Hesp, P. A. 1999. The beach backshore and beyond. Handbook of beach and shoreface morphodynamics 145-170. New York: Wiley.

Hesp, P. A. 2002. Foredunes and blowouts: Initiation, geomorphology and dynamics. Geomorphology 48(1-2):245268.

Hesp, P. A., R. Davidson-Arnott, I. J. Walker, and J. Ollerhead. 2005. Flow dynamics over a foredune at Prince Edward Island, Canada. Geomorphology 65(1):71-84.

Hesp, P. A. 2012. Surfzone-beach-dune interactions. NCK-days 2012: Crossing borders in coastal research. Edited by W. M. Kranenburg, E. M. Horstman, K. M. Wijnberg. Jubilee Conference Proceedings 20th NCK-days, Netherlands Centre for Coastal Research (2012), 35-40 (Nederlands Centrum voor Kustonderzoek NCK, http://nck-web.org/) 4th Lustrum (20th Anniversary). http://doc.utwente.nl/86134/1/NCKdays2012.pdf

Hesp, P. A., I. J. Walker, C. Chapman, R. Davidson-Arnott, and B. O. Bauer. 2013. Aeolian dynamics over a coastal foredune, Prince Edward Island, Canada. Earth Surface Processes and Landforms 38(13):1566-1575.

Hesp, P. A., and T. A. Smyth. 2016. Jet flow over foredunes. Earth Surface Processes and Landforms 41(12):17271735 .

Houser, C., and B. Greenwood. 2003. Response of a swash bar to a sequence of storms. In Proceedings Coastal Sediments (Vol. 3). Reston, VA: American Society of Civil Engineers. 
Houser, C., C. Hapke, and S. Hamilton. 2008. Controls on coastal dune morphology, shoreline erosion and barrier island response to extreme storms. Geomorphology 100(3-4):223-240.

Houser, C. 2009. Synchronization of transport and supply in beach-dune interaction. Progress in Physical Geography 33(6):733-746.

Houser, C., and S. Hamilton. 2009. Sensitivity of post-hurricane beach and dune recovery to event frequency. Earth Surface Processes and Landforms 34(5):613-628.

Houser, C. 2013. Alongshore variation in the morphology of coastal dunes: Implications for storm response. Geomorphology 199:48-61.

Houser, C., P. Wernette, E. Rentschlar, H. Jones, B. Hammond, and S. Trimble. 2015. Post-storm beach and dune recovery: Implications for barrier island resilience. Geomorphology 234:54-63.

Houser, C., and S. Mathew. 2011. Variability in foredune height depends on the alongshore correspondence of transport potential and sediment supply. Geomorphology 125(1):62-72.

Larson, M., L. Erikson, and H. Hanson. 2004. An analytical model to predict dune erosion due to wave impact. Coastal Engineering 51(8-9):675-696.

Lee, G. H., R. J. Nicholls, and W. A. Birkemeier. 1998. Storm-driven variability of the beach-nearshore profile at Duck, North Carolina, USA, 1981-1991. Marine Geology 148(3):163-177.

Masselink, G., A. Kroon, and R. G. D. Davidson-Arnott. 2006. Morphodynamics of intertidal bars in wave-dominated coastal settings - a review. Geomorphology 73(1-2):33-49.

McLean, R., and J. S. Shen. 2006. From foreshore to foredune: Foredune development over the last 30 years at Moruya Beach, New South Wales, Australia. Journal of Coastal Research 22(1):28-36.

Morton, R. A., J. G. Paine, and J. C. Gibeaut. 1994. Stages and durations of post-storm beach recovery, southeastern Texas coast, USA. Journal of Coastal Research 10(4):884-908.

Nishi, R., and N. C. Kraus. 1996. September. Mechanism and calculation of sand dune erosion by storms. In Coastal Engineering Conference 3:3034-3047. Reston, VA: American Society of Civil Engineers.

Nordstrom, K. F., and N. L. Jackson. 1993. The role of wind direction in eolian transport on a narrow sandy beach. Earth Surface Processes and Landforms 18(8):675-685.

Palmsten, M. L., and R. A. Holman. 2011. Infiltration and instability in dune erosion. Journal of Geophysical Research: Oceans 116(C10).

Palmsten, M. L., and R. A. Holman. 2012. Laboratory investigation of dune erosion using stereo video. Coastal Engineering 60(0):123-135.

Pries, A. J., D. L., and L. C. Branch. 2008. Identification of structural and spatial features that influence storm-related dune erosion along a barrier-island ecosystem in the Gulf of Mexico. Journal of Coastal Research 24(sp3)(4A):168-175.

Ruggiero, P., G. M. Kaminsky, G. Gelfenbaum, and N. Cohn. 2016. Morphodynamics of prograding beaches: A synthesis of seasonal-to century-scale observations of the Columbia River littoral cell. Marine Geology 376:5168 .

Ruggiero, P., D. J. R. Walstra, G. Gelfenbaum, and M. Van Ormondt. 2009. Seasonal-scale nearshore morphological evolution: Field observations and numerical modeling. Coastal Engineering 56(11-12):1153-1172. 
Sallenger, A. H., Jr. 2000. Storm impact scale for barrier islands. Journal of Coastal Research 16(3):890-895.

Sallenger, A., C. W. Wright, and J. Lillycrop. 2007. Coastal-change impacts during Hurricane Katrina: an overview. In Coastal Sediments '07: Sixth International Symposium on Coastal Engineering and Science of Coastal Sediment Processes: Proceedings, 888-896.

Sherman, D. J., and S. Hotta. 1990. Aeolian sediment transport: Theory and measurement. Coastal Dunes: Form and Process 17:37.

Sherman, D. J., and B. O. Bauer. 1993. Dynamics of beach-dune systems. Progress in Physical Geography 17(4):413447.

Sherman, D. J., and W. Lyons. 1994. Beach-state controls on aeolian sand delivery to coastal dunes. Physical Geography 15(4):381-395.

Short, A. D., and P. A. Hesp. 1982. Wave, beach and dune interactions in southeastern Australia. Marine geology 48(34):259-284.

Splinter, K. D., and M. L. Palmsten. 2012. Modeling dune response to an east coast low. Marine Geology 329331(0):46-57.

Splinter, K. D., J. T. Carley, A. Golshani, and R. Tomlinson. 2014. A relationship to describe the cumulative impact of storm clusters on beach erosion. Coastal Engineering 83:49-55.

Swann, C., K. L. Brodie, and N. Spore. 2015. Coastal foredunes:identifying coastal, aeolian, and management interactions driving morphologic state change. ERDC/CHL TR-15-17. Vicksburg, MS: U.S. Army Engineer Research and Development Center.

Thieler, E. R., and R. S. Young. 1991. Quantitative evaluation of coastal geomorphological changes in South Carolina after Hurricane Hugo. Journal of Coastal Research Special Issue No. 8:187-200.

Walker, I. J., P. A. Hesp, R. G. Davidson-Arnott, and J. Ollerhead. 2006. Topographic steering of alongshore airflow over a vegetated foredune: Greenwich Dunes, Prince Edward Island, Canada. Journal of Coastal Research 22(5):1278-1291.

Walker, I. J., P. A. Hesp, R. G. Davidson-Arnott, B. O. Bauer, S. L. Namikas, and J. Ollerhead. 2009. Responses of three-dimensional flow to variations in the angle of incident wind and profile form of dunes: Greenwich Dunes, Prince Edward Island, Canada. Geomorphology 105(1-2):127-138.

Wolner, C. W., L. J. Moore, D. R. Young, S. T. Brantley, S. N. Bissett, and R. A. McBride. 2013. Ecomorphodynamic feedbacks and barrier island response to disturbance: Insights from the Virginia Barrier Islands, Mid-Atlantic Bight, USA. Geomorphology 199:115-128.

Wright, L. D., and A. D. Short. 1984. Morphodynamic variability of surf zones and beaches: A synthesis. Marine Geology 56(1-4):93-118.

Zarnetske, P. L., P. Ruggiero, E. W. Seabloom, and S. D. Hacker. 2015. Coastal foredune evolution: The relative influence of vegetation and sand supply in the US Pacific Northwest. Journal of the Royal Society Interface12(106). http://rsif.royalsocietypublishing.org/content/12/106/20150017

DISCLAIMER: The contents of this technical note are not to be used for advertising, publication, or promotional purposes. Citation of trade names does not constitute an official endorsement or approval of the use of such products. 